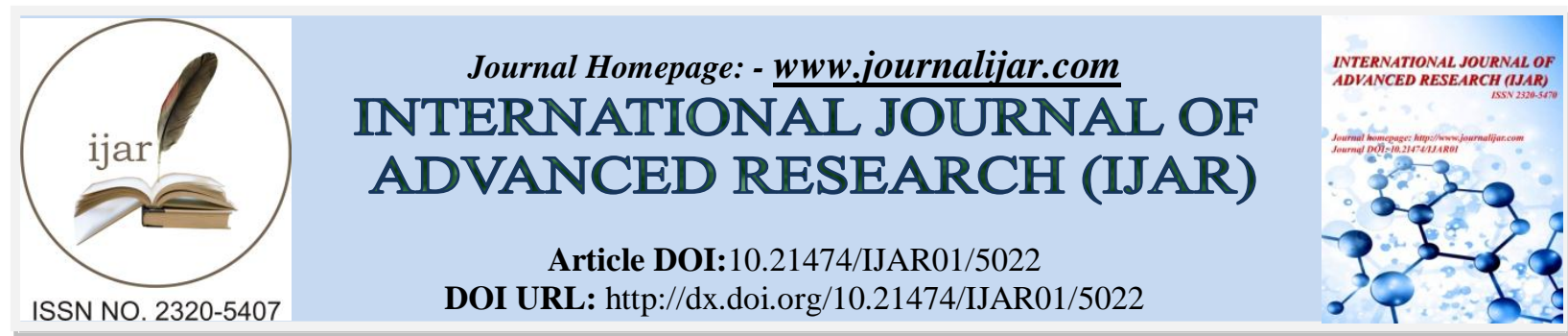

RESEARCH ARTICLE

\title{
THE DEVELOPMENT MODEL OF NAVAL TECHNOLOGY HIGHER EDUCATION TOWARD THE CENTER OF EXCELLENCE ON NAVAL ADN MARITIME SCIENCE
}

\author{
Sutrisno $^{1}$, Zaenal Fanani ${ }^{2}$, Harsuko Riniwati ${ }^{2}$ and Aminudin Afandhi ${ }^{2}$. \\ 1. Student of Doctorate Postgraduate Program in Environmental Science, Brawijaya University. \\ 2. Lecturer of Doctorate Postgraduate Program in Environmental Science, Brawijaya University.
}

\section{Manuscript Info}

Manuscript History

Received: 28 May 2017

Final Accepted: 30 June 2017

Published: July 2017

\section{Abstract}

Naval Technology Higher Education (STTAL) is a military higher education of research type that attempts to become a world-class higher education in military sector. To attain this goal, it must be able to deal with challenges and to explore any opportunities coming before it. One activity relevant to this goal is developing an education system to bring STTAL to be The Center of Excellence on Naval and Maritime Science to produce professional graduates. The objective of this research is to analyze the factors influencing the development of STTAL toward the Center of Excellence on Naval and Maritime Science and to find out the proper development model for STTAL to go toward the Center of Excellence on Naval and Maritime Science. Some variables and their indicators are included. Lecturer Human Resource is explained with indicators of scholar warrior, academic excellence, maritime science, naval science, technology information system, fresh student recruitment system, stakeholders, commercialization, utilization of research and development outputs, amarment system, and international research publication. All of them are influenced by lecturer human resource. Academic involves education, research, community service, learning method, and cooperation network. Education Facility includes laboratory and education structures. Institutional Reinforcement is described with higher education validation, quality assurance, lecturer fostering, operational cost, lecturer incentive, and lecturer performance expense. Motivation comprises of few indicators such as psychology, security, social orientation, recognition, and self-actualization. Compensation is determined by salary payment, incentive payment, facility, career, and work environment. Model used by STTAL to attain the goal toward the Center of Excellence on Naval and Maritime Science is by optimizing variables of lecturer human resource, academic, education facility, institutional reinforcement, motivation and compensation. Some indicators in the variables are needed for improvement. The soft-skill of lecturer human resource can be increased by sending them into off-the-job training. The study on the application of science and technology to naval and maritime sector could also improve the competence of lecturers. The procurement of laboratory instruments and the fostering of lecturers through sending them into conferences 
Seminar may help increasing their quality. The fostering of technical skill, the learning-duty for S3, and the innovation at armament system sector, are also important to create weapon system which facilitates the main duty of TNI in producing security at maritime sector.

Copy Right, IJAR, 2017,. All rights reserved.

\section{Introduction:-}

Weapon and material technologies recently used by Navy are getting more superior and ultimate. It needs human resource who have reliable knowledge and skill to properly operate and maintain these technologies. Naval Technology Higher Education (STTAL) is a research military higher education attended not only for attaining a certain grade point of average, but also becoming a place that helps the students to fulfill their demand to respond any changes on defense technologies. To attain the vision as the world-class research military higher education, then a systematic development strategy with sustainability orientation is therefore, needed. The paradigm of this worldclass research military higher education is presented through three excellences as found in other higher educations, respectively excellence on academic, excellence on research, and excellence on community service.

To become the Center of Excellence on Naval and Maritime Science, STTAL is required to have excellences on academic (education), research and community service. Excellence on academic is obtained from the best quality of educating staffs with national and international acknowledgment given to their scientific publication, the best quality of curriculum, and the reliable facility of education. Excellence on research is derived from the presence of experts on naval and maritime science, and also the existence of research program and research facility. Excellence on community service is acquired from the contribution of research to the benefits of community and education sector. Indeed, to be the Center of Excellence on Naval and Maritime Science, STTAL should consider some attributes such as: proper planning strategy to attain targets, organizational structure, information dissemination system, working staffs, proper managerial style to attain goals, employee's skill or competence, shared-value, and leadership that inspiring the staffs. STTAL as a military higher education of research type that attempts to become a world-class higher education in military sector must be able to explore opportunities to deal with the existing challenges. STTAL must develop an appropriate education system that drives it toward The Center of Excellence on Naval and Maritime Science to produce professional graduates. This research is aimed to analyze the factors influencing the development of STTAL toward the Center of Excellence on Naval and Maritime Science and to find out the proper development model for STTAL to go toward the Center of Excellence on Naval and Maritime Science.

\section{Method Of Research:-}

Sampling technique in this research is total sampling. It means that sample size is similar to population of respondents (Sugiyono, 2007). Total sampling is also a way to ensure that the sample is actually compatible with all research objects (Nursalam, 2008). The sample is 138 persons and all of them are STTAL lecturers. Data are collected by conducting survey to the location and giving questionnaire to respondents. Type of data obtained is primary and secondary data. Secondary data are compiled from structured interview by the author with 138 lecturers. Information obtained from representatives of STTAL managing board is also classified as secondary data. Meanwhile, primary data are the result after processing the data of structured interview. The structured type of interview is that the questions are strictly and properly preplanned.

\section{Inferential Statistic Analysis: GSCA:-}

Research attempts to formulate the models of the effect of Lecturer Human Resource on Academic, Education Facility, Institutional Reinforcement, Motivation and Compensation, and also the effect of Lecturer Human Resource on The Center of Excellence on Naval and Maritime Science (CoE Naval \& Maritime Science). The analysis technique in this case is Generalized Structure Component Analysis (GeSCA). As said by Solimun (2010) and Gozali (2008), the steps to analyze data with GeSCA method are explained as follows:

To design the structural model (relationship between latent variables).

To design the measurement model (reflexive or formative).

To construct Path Diagram.

To convert Path Diagram into Equation System.

To estimate Path Coefficient, Loading and Weight.

To evaluate Goodness of Fit. 
To attest hypotheses (Resampling Bootstrapping)

Both models of the effect of Lecturer Human Resource on Academic, Education Facility, Institutional Reinforcement, Motivation and Compensation, and also the effect of Lecturer Human Resource on CoE Naval \& Maritime Science, have been compatible with theories, empirical studies, and the adoption of inter-variable relationship from other science field.

\section{Discussion:-}

\section{Generalized Structure Component Analysis}

Result of data processing would be explained in the following.

\section{Path Diagram Construction}

GSCA is attesting the effect of Lecturer Human Resource (X1), Academic (Y1), Education Facility (Y2), Institutional Reinforcement (Y3), Motivation (Y4), Compensation (Y5), and CoE Naval \& Maritime Science (Z). Seven (7) latent variables are used in this research along with 39 indicators.

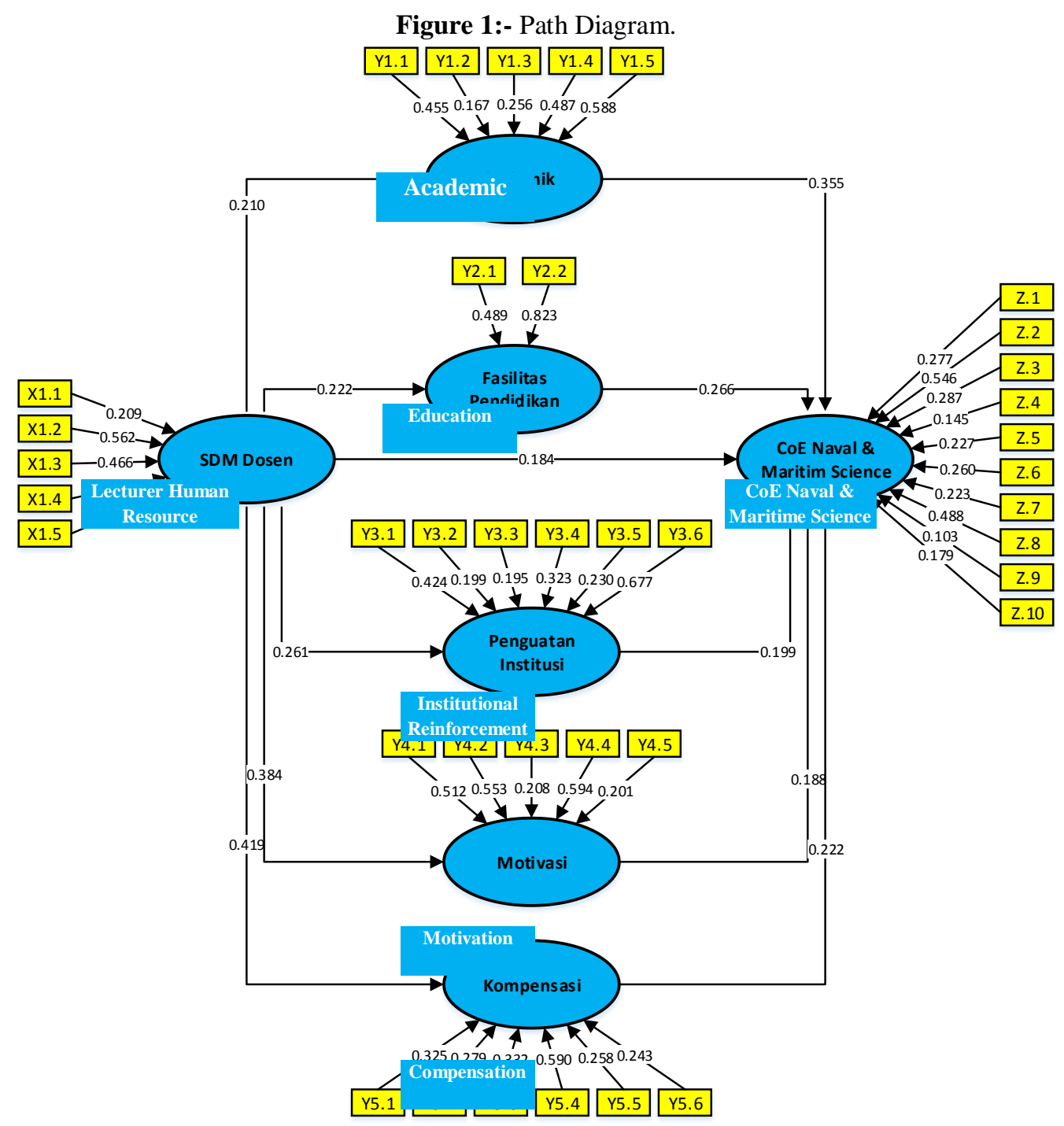

Hypothesis testing uses t-statistic value. If $t$-statistic value is greater than t-table value of 1.96 , then the effect is considered as significant. Result of hypothesis testing based on GSCA model is elaborated as follows.

Effect on Academic (Y1)

The effect of Lecturer Human Resource (X1) on Academic (Y1) is shown in Table 
Table 1:- Hypothesis Test Result of Direct Effect on Academic (Y1).

\begin{tabular}{|l|l|l|l|l|}
\hline Hypothesis & Effect & Coefficient & t-statistic & Remark \\
\hline 1 & Lecturer Human Resource $(\mathrm{X} 1) \rightarrow$ Academic (Y1) & 0.210 & 2.647 & Significant \\
\hline
\end{tabular}

Source: Research data are processed (2017).

The testing of the effect of Lecturer Human Resource (X1) on Academic (Y1) has resulted in t-statistic (2.647) > ttable (1.960), which means that the effect of Lecturer Human Resource (X1) on Academic (Y1) is significant at 5\% significance level. Path coefficient $(0.210)$ has positive sign indicating the existence of positive effect. In other words, the better is Lecturer Human Resource (X1), the better also is Academic (Y1). As noted Christiani (2013), lecturer refers to one of learning process components with great contribution to the creation of potential human resources for development efforts, due to the knowledge they have, and also with high responsibility to guide the educated participants into the persons of intellectualism.

According to Dwipurwani et.al., (2012), some factors have influenced learning-teaching process, and these include human resource of lecturing staff (lecturer), curriculum and structure-infrastructure. The quality of lecturer is determined by the completion of formal education, their expertise of teaching, and the mastery of material to be taught. Their performance to implement Tri Dharma of the higher education, including education, research and community service, however, is not the indicator to lecturer quality. It is surprising regarding to the fact that the professionalism of lecturers in research and community service is meaningful to improve the quality of their main duty in teaching and educating students.

In research sector, for example, lecturers may take great benefit from upgrading their knowledge. The knowledge they transfer to students is always newly based information. Knowledge updating would facilitate the universal function of higher education, respectively: to develop human resource by educating them with science and technology to produce the graduates on the request of stakeholders. Through community service, lecturers have opportunities to participate directly into problem-solving amid the community, and also to increase their knowledge about community's demand for education.

Effect on Education Facility (Y2):-

The effect of Lecturer Human Resource (X1) on Education Facility (Y2) is indicated in Table 2.

Table 2:- Hypothesis Test Result of Direct Effect on Education Facility (Y2).

\begin{tabular}{|l|l|l|l|l|}
\hline Hypothesis & Effect & Coefficient & t-statistic & Remark \\
\hline 2 & Lecturer Human Resource $(\mathrm{X} 1) \rightarrow$ Education Facility (Y2) & 0.222 & 2.300 & Significant \\
\hline
\end{tabular}

Source: Research data are processed (2017).

The testing of the effect of Lecturer Human Resource (X1) on Education Facility (Y2) has produced t-statistic (2.300) > t-table (1.960), which means that the effect of Lecturer Human Resource (X1) on Education Facility (Y2) is significant at $5 \%$ significance level. Path coefficient $(0.222)$ is positively signed indicating that positive effect exists. Thus, the better is Lecturer Human Resource (X1), the better also is Education Facility (Y2). The improvement of STTAL Lecturer Human Resource would be followed by better procurement of Education Facility including laboratory and education structure. It may precede the achievement of higher education's Tri Dharma. Higher education performance would improve if it is supported by reliable structure, infrastructure, or facility to deliver learning-teaching activity. Asiabaka (2008) has asserted that facility plays important role in actualization of education goals and targets, and in the fulfillment of physical and emotional demands of staffs and students in higher education. Learning facility is always needed by educated participants to facilitate and optimize their learning process. The facility may take a form as building and learning facility. Structure and infrastructure have complied with the standard stated in Government Regulation No.19/2005 on Education National Standard, amended by Governemnt Regulation No.32/2013 on The Amendment of Government Regulation No.19/2005. Structure and infrastructure in this matter include learning room, gymnasium, prayer spot, library, laboratory, workshop, and other learning source. All of them are needed to support learning process, including the use of information and communication technology. 
Effect on Institutional Reinforcement (Y3):-

Table 3 shows the effect of Lecturer Human Resource (X1) on Institutional Reinforcement (Y3).

Table 3:- Hypothesis Test Result of Direct Effect on Institutional Reinforcement (Y3).

\begin{tabular}{|l|l|l|l|l|}
\hline $\begin{array}{l}\text { Hypothesi } \\
\mathrm{s}\end{array}$ & Effect & $\begin{array}{l}\text { Coefficien } \\
\mathrm{t}\end{array}$ & $\begin{array}{l}\mathrm{t}- \\
\text { statistic }\end{array}$ & Remark \\
\hline 3 & $\begin{array}{l}\text { Lecturer Human Resource }(\mathrm{X} 1) \rightarrow \text { Institutional Reinforcement } \\
(\mathrm{Y} 3)\end{array}$ & 0.261 & 2.531 & $\begin{array}{l}\text { Significan } \\
\mathrm{t}\end{array}$ \\
\hline
\end{tabular}

Source: Research data are processed (2017).

The effect of Lecturer Human Resource (X1) on Institutional Reinforcement (Y3) has been tested, and resulted in tstatistic (2.531) > t-table (1.960), meaning that the effect of Lecturer Human Resource (X1) on Institutional Reinforcement (Y3) is significant at significance level of 5\%. Path coefficient $(0.261)$ has positive sign which justifies the existence of positive effect. It can be said that the better is Lecturer Human Resource (X1), the better also is Institutional Reinforcement (Y3). Human is not different from money capital, raw material, and production machine. De-humanizing process has sent human nowadays into suffering from being replaced by computer and ultimate technology. Deep review on this topic has declared a fact that the main success to achieve organizational goal remains on its human resource. The advance and sophistication of technology, the development of information, and the provision of reliable structure-infrastructure, but without feasible human resource, would only bring difficulty for the organization in pursuing the goals. Therefore, organizational human resources must be given a good recognition because it helps maximizing contribution to organization and performance development.

Each organization regardless its shape, either profit oriented, such as company and industry, or non-profit, including government institution, education institution, socio-community organization, religious organization, and even political organization, must have variety of goals to achieve.

The goals would be achieved by using the existing resources, including human resource. Thus, Human Resource Management (HRM) is concerning with how to utilize, develop, examine, respond, and manage the individuals as the member of organization. HRM also talks about designing and implementing the planning system, arranging and developing employees' career, performing evaluation, and settling compensation. HRM involves many managerial decisions and practices which directly influence human resource - people who work for organization. The better is the management of human resource in organization, the better also is the capacity of organization in achieving the goals in the future. If organizational human resource is not well managed, employees experience their effectiveness declining faster and sharper than other resources owned by organization. The decrease of human resource has greater effect on organizational effectiveness if compared to the decline of other resources.

Long, Ibrahim, \& Kowang (2014) in a study titled with An Analysis on the Relationship between Lecturers' Competencies and Students' Satisfaction have took quotes from Cohen (2000) and Theall \& Franklin (2001) who similarly stated that teaching and learning are two dimensions in academic world, and both depend on lecturer resource.

Effect on Motivation (Y4):-

Table 4 indicates the effect of Lecturer Human Resource (X1) on Motivation (Y4).

Table 4:-Hypothesis Test Result of Direct Effect on Motivation (Y4).

\begin{tabular}{|l|l|l|l|l|}
\hline Hypothesis & Effect & Coefficient & t-statistic & Remark \\
\hline 4 & Lecturer Human Resource $(\mathrm{X} 1) \rightarrow$ Motivation (Y4) & 0.384 & 4.468 & Significant \\
\hline
\end{tabular}

Source: Research data are processed (2017).

The effect of Lecturer Human Resource (X1) on Motivation (Y3) has subjected to the test and the result shows that $\mathrm{t}$-statistic (4.468) > t-table (1.960), meaning that the effect of Lecturer Human Resource (X1) on Motivation (Y4) is significant at $5 \%$ significance level. Path coefficient (0.384) is signed positively which confirms the existence of positive effect. It can be said that the better is Lecturer Human Resource (X1), the better also is Motivation (Y4). The improvement of human resource would increase lecturer's work motivation and work quality. Lecturer is also a driving force or an actor of development who would be helpful in attaining goals and targets of national development. Human resource as development core is an input (or a factor) that determines the motivation to attain development success, or also the desired output from national development activity. 


\section{Effect on Compensation (Y5):-}

The effect of Lecturer Human Resource (X1) on Compensation (Y5) is shown in Table 5.

Table 5:-Hypothesis Test Result of the Direct Effect on Compensation (Y5).

\begin{tabular}{|l|l|l|l|l|}
\hline Hypothesis & Effect & Coefficient & t-statistic & Remark \\
\hline 5 & $\begin{array}{l}\text { Lecturer Human Resource } \\
(\mathrm{X} 1) \rightarrow \text { Compensation (Y5) }\end{array}$ & 0.419 & 5.746 & Significant \\
\hline
\end{tabular}

Source: Research data are processed (2017).

Result of testing the effect of Lecturer Human Resource (HR) (X1) on Compensation (Y5) indicates that that tstatistic (5.746) > t-table (1.960), which means that there is significant effect of Lecturer Human Resource (X1) on Compensation (Y5) at 5\% significance level. Path coefficient (0.4190) is signed positively which supports the fact that positive effect exits. Thus, the better is Lecturer Human Resource (X1), the better also is Compensation (Y5). The improving lecturer human resource would increase lecturer's compensation. As said by Veithzal Rivai (2008), compensation is one of human resource functions related with all kinds of individual recognition in exchange for organizational works the employee has accomplished.

Effect on CoE Naval \& Maritime Science $(Z):-$

CoE Naval \& Maritime Science (Z) was influenced by Lecturer HR (X1), Academic (Y1), Education Facility (Y2), Institutional Reinforcement (Y3), Motivation (Y4), and Compensation (Y5).

Table 6:- Hypothesis Test Result of the Direct Effect on CoE Naval \& Maritime Science (Z).

\begin{tabular}{|c|c|c|c|c|}
\hline Hypotheses & Effect & Coefficient & t-statistic & Remark \\
\hline 6 & $\begin{array}{c}\text { Lecturer HR }(\mathrm{X} 1) \rightarrow \text { CoE Naval \& Maritime } \\
\text { Science }(\mathrm{Z})\end{array}$ & 0.184 & 2.032 & $\begin{array}{c}\text { Significa } \\
\text { nt }\end{array}$ \\
\hline 7 & $\begin{array}{c}\text { Academic }(\mathrm{Y} 1) \underset{\text { Science }(\mathrm{Z})}{\rightarrow} \text { CoE Naval \& Maritime } \\
\text { Sciencing }\end{array}$ & 0.355 & 3.488 & $\begin{array}{c}\text { Significa } \\
\text { nt }\end{array}$ \\
\hline 8 & $\begin{array}{c}\text { Education Facility (Y2) } \rightarrow \text { CoE Naval } \\
\& \text { Maritime Science }(\mathrm{Z})\end{array}$ & 0.266 & 3.268 & $\begin{array}{c}\text { Significa } \\
\text { nt }\end{array}$ \\
\hline 9 & $\begin{array}{c}\text { Institutional Reinforcement (Y3) } \rightarrow \text { CoE Naval } \\
\& \text { Maritime Science }(\mathrm{Z})\end{array}$ & 0.199 & 2.142 & $\begin{array}{c}\text { Significa } \\
\text { nt }\end{array}$ \\
\hline 10 & $\begin{array}{c}\text { Motivation (Y4) } \rightarrow \text { CoE Naval \& Maritime } \\
\text { Science }(\mathrm{Z})\end{array}$ & 0.188 & 2.165 & $\begin{array}{c}\text { Significa } \\
\text { nt }\end{array}$ \\
\hline 11 & $\begin{array}{c}\text { Compensation (Y5) } \rightarrow \text { CoE Naval \& Maritime } \\
\text { Science }(\mathrm{Z})\end{array}$ & 0.222 & 2.100 & $\begin{array}{l}\text { Significa } \\
\text { nt }\end{array}$ \\
\hline
\end{tabular}

Source: Research data are processed (2017).

Result of testing the effect of Lecturer HR (X1) on CoE Naval \& Maritime Science (Z) has showed that t-statistic $(2.032)>t$-table (1.960) meaning that there is a significant effect from Lecturer HR (X1) on CoE Naval \& Maritime Science $(Z)$ at $5 \%$ significance level. Path coefficient $(0.184)$ has positive sign which supports the fact that positive effect exists. Thus, it can be said that the better is Lecturer HR (X1), the better also is CoE Naval \& Maritime Science $(Z)$.

The effect of Academic (Y1) on CoE Naval \& Maritime Science (Z) has been attested resulting in t-statistic (3.488) $>\mathrm{t}$-table (1.960) meaning that a significant effect is found from Academic (Y1) on CoE Naval \& Maritime Science (Z) at 5\% significance level. Path coefficient (0.355) has positive sign which indicates that positive effect exists. It can be declared that the better is Academic (Y1), the better also is CoE Naval \& Maritime Science (Z).

The testing of the effect of Education Facility (Y2) on CoE Naval \& Maritime Science (Z) has been done indicating t-statistic (3.268) > t-table (1.960) which means that the effect of Education Facility (Y2) on CoE Naval \& Maritime Science $(Z)$ is significant at significance level of 5\%. Path coefficient (0.266) is positively signed which confirms the existence of positive effect. It means that the better is Education Facility (Y2), the better also is CoE Naval \& Maritime Science (Z).

The testing of the effect of Institutional Reinforcement (Y3) on CoE Naval \& Maritime Science (Z) has been conducted resulting in t-statistic (2.142) > t-table (1.960) which means that the effect of Institutional Reinforcement (Y3) on CoE Naval \& Maritime Science (Z) is significant at significance level of 5\%. Path coefficient (0.199) is 
positively signed which declares the existence of positive effect. The better is Institutional Reinforcement (Y3), the better also is CoE Naval \& Maritime Science $(Z)$.

The effect of Motivation (Y4) on CoE Naval \& Maritime Science (Z) has been subjected to the test, and the result shows that t-statistic (2.165) > t-table (1.960) meaning that a significant effect is apparent from Motivation (Y4) on CoE Naval \& Maritime Science (Z) at 5\% significance level. Path coefficient (0.188) has positive sign which indicates that positive effect exists. It means that the better is Motivation (Y4), the better also is CoE Naval \& Maritime Science (Z).

The effect of Compensation (Y5) on CoE Naval \& Maritime Science (Z) has also been examined, and the result indicates that t-statistic (2.100) > t-table (1.960) meaning that Compensation (Y4) has significant effect on $\mathrm{CoE}$ Naval \& Maritime Science $(Z)$ at 5\% significance level. Path coefficient $(0.222)$ has positive sign which confirms the existence of positive effect. It is said therefore that the better is Compensation (Y5), the better also is CoE Naval \& Maritime Science $(\mathrm{Z})$.

Table 7:-Hypothesis Test Result of the Indirect Effect on CoE Naval \& Maritime Science (Z).

\begin{tabular}{|l|l|l|l|l|}
\hline $\begin{array}{l}\text { Hypothe } \\
\text { ses }\end{array}$ & Effect & $\begin{array}{l}\text { Coeffici } \\
\text { ent }\end{array}$ & $\begin{array}{l}\text { t- } \\
\text { statisti } \\
\text { c }\end{array}$ & Remark \\
\hline 12 & $\begin{array}{l}\text { Lecturer HR (X1) } \rightarrow \text { CoE Naval \& Maritime Science (Z) through } \\
\text { Academic (Y1) }\end{array}$ & 0.074 & 9.207 & $\begin{array}{l}\text { Signific } \\
\text { ant }\end{array}$ \\
\hline 13 & $\begin{array}{l}\text { Lecturer HR (X1) } \rightarrow \text { CoE Naval \& Maritime Science (Z) through } \\
\text { Education Facility (Y2) }\end{array}$ & 0.059 & 7.502 & $\begin{array}{l}\text { Signific } \\
\text { ant }\end{array}$ \\
\hline 14 & $\begin{array}{l}\text { Lecturer HR (X1) } \rightarrow \text { CoE Naval \& Maritime Science (Z) through } \\
\text { Institutional Reinforcement (Y3) }\end{array}$ & 0.052 & 5.413 & $\begin{array}{l}\text { Signific } \\
\text { ant }\end{array}$ \\
\hline 15 & $\begin{array}{l}\text { Lecturer HR (X1) } \rightarrow \text { CoE Naval \& Maritime Science (Z) through } \\
\text { Motivation (Y4) }\end{array}$ & 0.072 & 9.650 & $\begin{array}{l}\text { Signific } \\
\text { ant }\end{array}$ \\
\hline 16 & $\begin{array}{l}\text { Lecturer HR (X1) } \rightarrow \text { CoE Naval \& Maritime Science (Z) through } \\
\text { Compensation (Y5) }\end{array}$ & 0.093 & $\begin{array}{l}12.01 \\
8\end{array}$ & $\begin{array}{l}\text { Signific } \\
\text { ant }\end{array}$ \\
\hline
\end{tabular}

Source: Research data are processed (2017).

The testing of the effect of Lecturer HR (X1) on CoE Naval \& Maritime Science (Z) through Academic (Y1) has been conducted and resulting in t-statistic (9.207) $>$ t-table (1.960) which means that there is a significant effect from Lecturer HR (X1) on CoE Naval \& Maritime Science (Z) through Academic (Y1) at 5\% significance level. Its path coefficient (0.074) is positively signed which indicates positive effect existence. It means that the better is Lecturer HR (X1), the better also is CoE Naval \& Maritime Science (Y) through Academic (Y1).

The testing of the effect of Lecturer HR (X1) on CoE Naval \& Maritime Science (Z) through Education Facility (Y2) has been performed and showing that t-statistic (7.502) $>\mathrm{t}$-table (1.960) which means that there is a significant effect from Lecturer HR (X1) on CoE Naval \& Maritime Science (Z) through Education Facility (Y2) at 5\% significance level. Its path coefficient $(0.058)$ has positive sign which indicates that positive effect exists. It can be said that the better is Lecturer HR (X1), the better also is CoE Naval \& Maritime Science (Z) through Education Facility (Y2).

The testing of the effect of Lecturer HR (X1) on CoE Naval \& Maritime Science (Z) through Institutional Reinforcement (Y3) has been done and indicating t-statistic (5.413) >t-table (1.960) meaning that the effect of Lecturer HR (X1) on CoE Naval \& Maritime Science (Z) through Institutional Reinforcement (Y3) is significant at significance level of $5 \%$. Path coefficient $(0.052)$ is positively signed which confirms the existence of positive effect, and which also means that the better is Lecturer HR (X1), the better also is CoE Naval \& Maritime Science (Z) through Institutional Reinforcement (Y3). This finding is consistent with Arikuntoro (2000) who asserted that human resource is the only resource with intellectual, desire, competence, skill, knowledge, curiosity and willing. The potential in any human resources may influence the achievement of organizational goals. Human is important resource because the advance of technology, the development of information system, and the existence of reliable structure-infrastructure still trap the organization into difficulty from pursuing the goals if feasible human resource is not available. Indeed, human feasibility is related with institutional reinforcement. Material Resources would be useless without Human Resources. 
Human resource as the component of education can be considered as the key of educational success, and they must be fostered and developed continually to improve their quality, at least in carrying out their function professionally. Professional human resource with good quality is an absolute necessity for improving education quality. The question is how to manage this human resource to optimize the production of education in better quality. No simple answer is found. The lack of simplicity is related with the definition of management itself.

The effect of Lecturer HR (X1) on CoE Naval \& Maritime Science (Z) through Motivation (Y4) has been subjected to the test and the result indicates that t-statistic (9.650) > t-table (1.960) meaning that the effect of Lecturer HR (X1) on CoE Naval \& Maritime Science (Z) through Motivation (Y4) is significant at 5\% significance level. Path coefficient (0.072) has positive sign which supports the fact that positive effect exists. It means that the better is Lecturer HR (X1), the better also is CoE Naval \& Maritime Science (Z) through Motivation (Y4).

The effect of Lecturer HR (X1) on CoE Naval \& Maritime Science (Z) through Compensation (Y5) has been subjected to examination and the result shows that t-statistic (12.018) > t-table (1.960) meaning that the effect of Lecturer HR (X1) on CoE Naval \& Maritime Science (Z) through Compensation (Y5) is significant at 5\% significance level. Its path coefficient (0.093) has positive sign which asserts the fact that positive effect exists. It can be said that the better is Lecturer HR (X1), the better also is CoE Naval \& Maritime Science (Z) through Compensation (Y5).

\section{Conclusion:-}

The development of Naval Technology Higher Education (STTAL) toward the Center of Excellence on Naval and Maritime Science involves the efforts to improve some variables and their indicators. Lecturer Human Resource is a variable explained by indicators of scholar warrior, academic excellence, maritime science, naval science, technology information system, fresh student recruitment system, stakeholders, commercialization, utilization of research and development outputs, amarment system, and international research publication. All of them are influenced by lecturer human resource. Academic is a variable involving education, research, community service, learning method, and cooperation network. Education Facility is a variable indicated by laboratory and education structures. Institutional Reinforcement is a variable described with indicators of higher education validation, quality assurance, lecturer fostering, operational cost, lecturer incentive, and lecturer performance expense. Motivation is a variable comprised of few indicators such as psychology, security, social orientation, recognition, and self-actualization. Compensation is a variable determined by indicators of salary payment, incentive payment, facility, career, and work environment.

Model used by STTAL to attain the goal toward the Center of Excellence on Naval and Maritime Science is by optimizing variables of lecturer human resource, academic, education facility, institutional reinforcement, motivation and compensation. Some indicators must still be improved. The soft-skill of lecturer human resource can be increased by sending them into off-the-job training. The study on the application of science and technology to naval and maritime sector could also improve the competence of lecturers. The procurement of laboratory instruments and the fostering of lecturers by sending them into international seminar may help increasing their quality. The fostering of technical skill, the learning-duty for S3, and the innovation at armament system sector, are also important to create weapon system which facilitates the main duty of TNI in producing security at maritime sector.

\section{Suggestion:-}

Lecturer Human Resource should be improved by fostering lecturer in some activities such as review, research, and development of science and technology related with defense and military action on naval and maritime sector to increase the mastery, development and utilization of this science and technology in order to increase the power and competence of TNI or TNI AL with reliability, integrative capacity and capability on community service.

The fostering of relevant personnel can be initiated through cooperation network with domestic and foreign institutions. Public relations should be also functional to improve the role of STTAL in community.

Academic and non-academic staffs must be sent into the fostering and development sessions to optimize their work at STTAL environment. 


\section{References:-}

1. Atmodiwiryo, Soebagio, Manajemen Pendidikan Indonesia, Jakarta: PT.Ardadizyan Jaya, 2000.

2. Decenzo, David A and Stepen P.Robbins, Human Resource Manajemen, New York: Jhon Willey and Sons Inc, 1999.

3. Desler, Gery, Personal Management (Manajemen Sumber Daya Manusia), Jakarta: Prenhalindo, 1997.

4. French, Wendell, The Personal Management Process, Hoston: Houghton Mifflin Company, 1993.

5. Gomes, Faustino Cardoso, Manajemen Sumber Daya Manusia, Yogyakarta: Andi Offset, 2001.

6. Handoko, T Hani, Manajemen Edisi 2. Yogyakarta: BPFE, 1995.

7. Melayu SP Hasibuan, Manajemen Sumber Daya Manusia, Jakarta: Bumi Aksara, 2001.

8. Mamduh Hanafi, Manajemen, Yogyakarta: UPP AMP YKPN, 1987.

9. Masri Singarimbun, Metode Penelitian Survey, Jakarta: LP3ES, 1999.

10. Mastuki HS.DKK, Manajemen Pondok pesanttren, Jakarta: Diva Pustaka, 2003.

11. Mathis, Robert dan Jhon H Jakson, Manajemen Sumber Daya Manusia, Jakarta: Salemba Empat, 2001.

12. Milles, MB \& Huberman MA, Qualitative Data Analisys a Source Book of New Method, London: Sage Publication Ltd. Moleong, Lexy J, Metodologi Penelitian Kualitatif, Bandung: Remaja Rosda Karya, 2006. Nasution S, Penelitian Naturalistik Kualitatif, Bandung: Tarsito, 1992.

13. Nawawi, Handari, Manajemen Strategic Organisasi non Profit di Bidang Pemerintahan, Yogyakarta: Gadjah Mada Universitas Press, 1999.

14. Nawawi, Handari, Manajemen Sumber Daya Manusia, Yogyakarta: Gadjah Mada Universitas Press, 2005.

15. PB, Trion, Paradigma Baru Manajemen Sumber Daya Manusia, Yogyakarta: Tugu, 2002.

16. Simamura, Henry, Manajemen Sumber Daya Manusia, Yogyakarta: STIE YKPN, 2004.

17. Sondang, P.Siagian, Manajemen Sumber Daya Manusia, Jakarta: PT.Bumi Aksara, 2008.

18. Sukarno, Dasar-Dasaer Manajemen, Bandung: PT.Masdar Maju, 1992.

19. Sukmadinata, Nana Saodih, Metode Penelitian Pendidikan, Bandung: Remaja Rosda Karya, 2005.

20. Sunyoto Usman, Pembangungan dan Pemberdayaan Masyarakat, Yogyakarta: Pustaka Pelajar Offset, 2006.

21. Sutisna, Oteng, Administrasi Pendidikan, Bandung: Angkasa, 1983.

22. Syamsy, Ibnu, Pokok-Pokok Organisasi dan Manajemen, Bandung: Remaja Rosda Karya, 1994.

23. W.J.S, Purwadarminta, Kamus Umum Bahasa Indonesia, Jakarta: PN Balai Pustaka, 1976. 